\title{
Antibiotic Sensitivity Pattern of Bacteria from Selected Hospitals in Akungba Akoko, Ondo State, Southwest Nigeria
}

\author{
${ }^{1}$ Temitope Olowokere, ${ }^{* 1}$ Mutiu A. Alabi, ${ }^{2}$ Bamidele S. Fagbohunka, ${ }^{1}$ Rita M. \\ Sunday, ${ }^{1}$ Ekundayo T. Salami, ${ }^{1}$ Folake Osanaiye, ${ }^{1}$ Johnson F. Afolabi and \\ ${ }^{1}$ Taiwo Otunla \\ ${ }^{I}$ Molecular Biology/Bioinformatics Unit, Bioresources Development Centre, National Biotechnology \\ Development Agency, Ogbomosho, Nigeria \\ ${ }^{2}$ Biochemistry Department, Obafemi Awolowo College of Health Sciences, Faculty of Basic Medical Sciences, \\ Olabisi Onabanjo University, Ago-Iwoye, Nigeria
}

\begin{abstract}
In recent times, there has been an astronomical increase in the cases of bacterial resistance to commonly used antibiotics by medical personnel in Akungba Akoko,Ondo State,Nigeria.It is just right for a study of this nature to be carried out in order to provide the important microbiological pieces of information to help medical practitioners to tackle this menance.Bacteria were isolated from inanimate object in hospitals in Ondo State which include: General Hospital, Iwaro-Oka; Reva Clinic, Akungba Akoko; University Health Centre, Akungba Akoko; and Comprehensive Health Centre, Akungba Akoko. In this study seven organism were isolated, Staphylococcus aureus, Streptococcus sp, Pseudomonas sp, Aeruginosa sp, Klebsiella sp, Bacillus sp and Escherichia coli. All these organisms were identified based on their morphology and biochemical characteristics. The incidence of Staphylococcusaureus (34.8\%) was found to be dominant out of the grampositive bacteria isolated. The incidence of E. coli (44.4\%) was found dominant out of the gram-negative bacteria isolated. Of the 70 isolates recovered, 43 (61.4\%) were gram-positive while 27 (38.6\%) were gramnegative. Multiple resistances were recorded against antibiotics used in this study. This study reveals that staphylococci, streptococci, bacillus, pseudomonas and enterbacteriaceae are predominant organism associated with inanimate object in hospitals. Effective hospital control and aseptic precaution will help reduce the incidence.
\end{abstract}

Keywords: bacteria, hospital, antibiotics, inanimate objects, antimicrobial.

\section{Introduction}

Antibiotics are antimicrobial agent produce by microorganism; they could be better described as any chemical of natural origin (i.e. from any type of cell) which can prevent the growth of other types of cell [1]. They are low molecular weight (non-protein) molecules produced as secondary metabolites mainly by microorganisms that live in the soil. Most of these organisms form spores or other forms of dominant cells, which may have some relationship between antibiotics production and the process of sporolation. The major mechanisms of resistance involve the introduction of mutation in genes encoding penicillin-binding protein and as reported, that selective pressure in thought to play an important role and the use of beta-lactam antibiotics has been implicated as risk factor for infection and colonization Streptococcus [2].

The $\beta$-lactam antibiotic of structural analogue of the D-alanyl-D-alanine and of the peptidoglycan strand, in the cell there are as many as seven enzymes (depending on the bacteria $s p$ ) which bind peptidoglycan unit via their D-alanyl-D-alanine residues. Enzyme binding $\beta$-lactam antibiotic are known as penicillin-binding protein $[3,4,5]$.

Several medically important antibiotic s own their selective antimicrobial action to a specific attack on the 70 s ribosome of bacteria with mammalian 80 s ribosome left unaffected. Those that act on the 30 s ribosomes are nitrofuran, gentamycin, streptomycin and neomycin while antibiotics that act on the 50s protein of the ribosome include, chloramphenicol, lincomycin, clidamycin, erythromycin and the inhibitor of metabolic pathways via competitive antagonism [6,7].

Antibiotic sensitivity is a term use to describe susceptibility of bacteria to antimicrobial. Antimicrobial susceptibility testing (AST) is usually carried out to determine while antibiotic will be most successful in treating a bacterial infection in vivo. Testing for the antimicrobial sensitivity is often done by the Kirby-Bauer disc diffusion technique [8]. A clear ring or zone of inhibition is seen around the water indicating poor growth if the bacteria are sensitive to antibiotics [6,9]. Antibiotic resistance involve naturally via natural selection acting upon random mutation [10].

The study is aimed at determining the incidence of gram-positive and gram-negative bacteria isolate and the antibiotic sensitivity pattern of the bacterial isolated. 


\section{Sample Collection}

\section{Materials And Methods}

The collection sample was from inanimate hospital source, sterile swab sticks were used to swab the surface of inanimate object such as bed hold, medical trolleys, door knobs, drip stands, wash hand basin and water closet inlets. The swab sticks were moister with sterile peptone water and were transported to the laboratory with an hour of sampling with proper labelling with information such as area sample serial number and hospital name etc.

\section{Preparation of Culture Media}

The culture media used was solids which were used in isolation and subsequent identification of the organism. The media were in dehydrated form obtain from nutrient agar, Marconky, biochemical 70148; lab (E05m) methylene blue mannitol salt agar.

\section{Isolation, Maintenance and Preservation of Cultures}

The sample were cultured using the streak plate method media such as nutrient agar, incubated at $37^{\circ} \mathrm{C}$ overnight and the isolates were collected as growth on these media. The cultures were maintained in slant of nutrient agar. The slants were kept in the refrigerator at $4^{\circ} \mathrm{C}$ until when needed in further experiments . The characterization and identification of various organisms were done by caring out biochemical characterization, catalase test, motility test, copulas test, methyl red voges-prostcaur test (the methyl red test is used to detect acid production while the voges-proslcacur test is used to show acetyl production). Sugar fermentation and antibiotic sensitivity tests were also carried out.

\section{Results}

Isolates identification was based on their cultural morphology and biochemical characteristics as shown in Table 1. The gram-positive organisms were smooth, opaque, irregular, entire, raised whitish, yellowish circular representing the morphology characteristics of staphylococcus, streptococcus and Bacillus. These gram positive do not show growth characteristics on Eosin methylene blue agar (EMB) but show growth characteristics on nutrient agar. However, gram negative stained scored negative to gram reaction showing different morphological characteristics as smooth, opaque, whitish round translucent, greenish, convex short rods and cured rod representing the genera of Klebsiella, Pseudomonas and Escherichia coli they show growth characteristics on EMB agar.

Out of the total gram positive organism 32 (74.42\%) were smooth, convex, opaque, yellow with entire edges, they appeared as cocci in irregular clusters and chain $11(25.58 \%)$ isolates were rough opaque with irregular edges and long rods with rounded ends.Of the 27(38.6\%) grain negative isolates 14 (51.85\%) appeared smooth convex and opaque with entire edges. They were short rods demonstrating a greenish metallic sheen, pinkish, large mucoid growth on EMB agar. The biochemical reactions of the bacterial isolates encountered in this study were also studied. Result of carbohydrate fermentation tests show that out of 70 isolates tested all reduced glucose to acid. Antibiotics resistance pattern of bacterial isolate, a total of 70 isolated with the various antibiotics enumerated in materials and all isolates were resistant to one or more antibiotics.

Table 2 showed bacteria isolates from hospital inanimate object in which Staphylococcus aureus was found to be $21.4 \%$, Escherichia coli was $17.5 \%$ and Streptococcus $s p$ was $15.7 \%$.

Table 3 showed the incidence of gram positive bacterial isolated from hospital inanimate object with Staphylococcus aureus having the highest incidence of $34.8 \%$. Whereas, Table 4 showed the incidence of gram negative bacterial isolated from hospital inanimate object with Escherichia coli having the highest incidence of $40.7 \%$.

Table 5 showed the antibiotic resistance of bacteria isolate from inanimate object in which five of the bacterial isolates are resistant to Augmentin (AUG), and four are resistant to Tetracycline (TET). 
Table 1: Characterization of Bacteria Isolate Cultured from Hospital Inanimate Object

\begin{tabular}{|c|c|c|c|c|c|c|c|c|c|c|c|c|c|c|c|c|c|}
\hline $\begin{array}{l}\text { I } \\
\text { s } \\
\text { o } \\
\text { l } \\
\text { a } \\
\text { t } \\
\text { e } \\
\text { s }\end{array}$ & $\begin{array}{l}\text { Cult } \\
\text { ural } \\
\text { mor } \\
\text { phol } \\
\text { ogy } \\
\text { On } \\
\text { nutr } \\
\text { ient } \\
\text { agar }\end{array}$ & $\begin{array}{l}\text { S } \\
\text { h } \\
\mathbf{a} \\
\mathbf{p} \\
\mathrm{e}\end{array}$ & $\begin{array}{l}\text { G } \\
\mathbf{r} \\
\mathbf{a} \\
\mathbf{m} \\
\mathbf{s} \\
\mathbf{t} \\
\mathbf{a} \\
\mathbf{i} \\
\mathbf{n}\end{array}$ & $\begin{array}{l}\text { M } \\
\text { ot } \\
\text { ili } \\
\text { ty }\end{array}$ & $\begin{array}{l}\text { catal } \\
\text { ase }\end{array}$ & $\begin{array}{l}\text { C } \\
\text { o } \\
\text { a } \\
\text { g } \\
\text { u } \\
\text { l } \\
\text { a } \\
\text { s } \\
\text { e }\end{array}$ & $\begin{array}{l}\text { I } \\
\text { n } \\
\text { d } \\
\text { o } \\
\text { l } \\
\text { e }\end{array}$ & $\begin{array}{l}\text { G } \\
\mathbf{r} \\
\mathbf{o} \\
\mathbf{w} \\
\mathbf{t} \\
\mathbf{h} \\
\mathbf{o} \\
\mathbf{n} \\
\mathbf{E} \\
\mathbf{M} \\
\mathbf{B} \\
\end{array}$ & $\begin{array}{l}\mathbf{M} \\
\mathbf{A}\end{array}$ & \begin{tabular}{l|}
$\mathbf{M}$ \\
$\mathbf{R}$
\end{tabular} & $\begin{array}{l}\mathbf{V} \\
\mathbf{P}\end{array}$ & $\begin{array}{l}\mathbf{G} \\
\mathbf{l} \\
\mathbf{u} \\
\mathrm{c} \\
\mathbf{0} \\
\mathrm{s} \\
\mathrm{e}\end{array}$ & $\begin{array}{l}\mathrm{S} \\
\mathbf{u} \\
\mathbf{c} \\
\mathbf{r} \\
\mathbf{o} \\
\mathrm{s} \\
\mathrm{e}\end{array}$ & $\begin{array}{l}\text { l } \\
\text { a } \\
\text { c } \\
\text { t } \\
\text { a } \\
\text { s } \\
\text { e }\end{array}$ & $\begin{array}{l}\text { M } \\
\mathbf{a} \\
\mathbf{l} \\
\mathbf{t} \\
\mathbf{a} \\
\mathrm{s} \\
\mathrm{e}\end{array}$ & $\begin{array}{l}\text { G } \\
\text { al } \\
\text { a } \\
\text { ct } \\
\text { a } \\
\text { se }\end{array}$ & $\begin{array}{l}\text { Id } \\
\text { en } \\
\text { tifi } \\
\text { ca } \\
\text { tio } \\
\text { n }\end{array}$ \\
\hline $\mathbf{A}$ & $\begin{array}{l}\text { Green, } \\
\text { smooth } \\
\text { flat dull }\end{array}$ & $\begin{array}{l}\text { Cur } \\
\text { ved } \\
\text { rod }\end{array}$ & - & + & + & - & + & $\begin{array}{l}\text { Trans } \\
\text { lucen } \\
\mathrm{t} \\
\text { colou } \\
\text { rless }\end{array}$ & $\begin{array}{l}\mathrm{M} \\
\mathrm{uc} \\
\text { oid } \\
\text { pur } \\
\text { ple }\end{array}$ & - & - & $\mathrm{A}$ & - & - & - & - & $\begin{array}{l}\text { Pseud } \\
\text { omona } \\
\text { s sp }\end{array}$ \\
\hline B & $\begin{array}{l}\text { Whitish, } \\
\text { smooth, } \\
\text { entire, } \\
\text { opaque }\end{array}$ & $\begin{array}{l}\text { Coc } \\
\text { ci in } \\
\text { chai } \\
n\end{array}$ & + & - & + & - & - & NG & $\begin{array}{l}\mathrm{N} \\
\mathrm{G}\end{array}$ & - & - & $\begin{array}{l}\mathrm{A} \\
\mathrm{G}\end{array}$ & A & A & A & $\mathrm{A}$ & $\begin{array}{l}\text { Strept } \\
\text { ococcu } \\
\text { s sp }\end{array}$ \\
\hline $\mathbf{C}$ & $\begin{array}{l}\text { Creamy } \\
\text { smooth, } \\
\text { opaque, } \\
\text { entire }\end{array}$ & $\begin{array}{l}\text { Shor } \\
\text { t rod }\end{array}$ & - & + & + & - & + & $\begin{array}{l}\text { Metal } \\
\text { ic } \\
\text { sheen }\end{array}$ & $\begin{array}{l}\text { Pin } \\
\text { kis } \\
\text { h }\end{array}$ & + & + & $\begin{array}{l}A \\
G\end{array}$ & $\mathrm{~A}$ & $\overline{\mathrm{AG}}$ & $\begin{array}{l}A \\
G\end{array}$ & $\mathrm{~A}$ & E.coli \\
\hline D & $\begin{array}{l}\text { Whitish, } \\
\text { entire, } \\
\text { smooth, } \\
\text { flat }\end{array}$ & $\begin{array}{l}\text { Lon } \\
\mathrm{g} \\
\text { rod }\end{array}$ & - & + & + & - & - & $\begin{array}{l}\text { Muco } \\
\text { id } \\
\text { pinki } \\
\text { sh }\end{array}$ & $\begin{array}{l}\mathrm{N} \\
\mathrm{G}\end{array}$ & + & + & $\begin{array}{l}\mathrm{A} \\
\mathrm{G}\end{array}$ & $\mathrm{A}$ & $\mathrm{A}$ & $\mathrm{A}$ & $\mathrm{A}$ & $\begin{array}{l}\text { Bacill } \\
\text { us sp }\end{array}$ \\
\hline $\mathbf{E}$ & $\begin{array}{l}\text { Opaque, } \\
\text { entire, } \\
\text { convex, } \\
\text { grayfish } \\
\text { white }\end{array}$ & Rod & - & - & + & NG & - & $\begin{array}{l}\text { Muco } \\
\text { id } \\
\text { brow } \\
n\end{array}$ & $\begin{array}{l}\mathrm{Re} \\
\mathrm{d}\end{array}$ & - & - & $\begin{array}{l}\mathrm{A} \\
\mathrm{G}\end{array}$ & $\begin{array}{l}\mathrm{A} \\
\mathrm{G}\end{array}$ & AG & $\begin{array}{l}\mathrm{A} \\
\mathrm{G}\end{array}$ & A & $\begin{array}{l}\text { klebsie } \\
\text { lla sp }\end{array}$ \\
\hline $\mathbf{F}$ & $\begin{array}{l}\text { Golden } \\
\text { yellow, } \\
\text { glossy } \\
\text { raised }\end{array}$ & $\begin{array}{l}\text { Coc } \\
\text { ci in } \\
\text { clust } \\
\text { er }\end{array}$ & + & - & + & + & - & NG & $\begin{array}{l}\mathrm{N} \\
\mathrm{G}\end{array}$ & + & + & A & A & - & $\bar{A}$ & A & $\begin{array}{l}\text { Staphy } \\
\text { lococc } \\
\text { us } \\
\text { aureus }\end{array}$ \\
\hline G & $\begin{array}{l}\text { Whitish, } \\
\text { smooth, } \\
\text { entire, } \\
\text { opaque }\end{array}$ & $\begin{array}{l}\text { Coc } \\
\text { ci in } \\
\text { clust } \\
\text { er }\end{array}$ & + & - & + & - & - & NG & $\begin{array}{l}\mathrm{N} \\
\mathrm{G}\end{array}$ & + & + & A & A & - & A & A & $\begin{array}{l}\text { Staphy } \\
\text { lococc } \\
\text { us sp }\end{array}$ \\
\hline
\end{tabular}

Key:

$\begin{array}{lll}\text { NG: No growth } & + \text { : positive } & \text {-: negative }\end{array}$ A: Acid Ag: Acid and gas

Table 2: Bacteria Isolates from Hospital Inanimate Object

\begin{tabular}{|l|l|l|}
\hline Isolate & Incidence & $\mathbf{\%}$ \\
\hline Pseudomonas $s p$ & 9 & 12.9 \\
\hline Streptococcus $s p$ & 11 & 15.7 \\
\hline Escherichia coli & 12 & 17.1 \\
\hline Bacillus $s p$ & 10 & 14.3 \\
\hline Klebsiella $s p$ & 7 & 10 \\
\hline Staphylococcus aureus & 15 & 21.4 \\
\hline Staphylococcus sp & 6 & 8.6 \\
\hline Total & 70 & 100 \\
\hline
\end{tabular}

Table 3: Incidence of Gram Positive Bacterial Isolated from Hospital Inanimate Object

\begin{tabular}{|l|l|l|}
\hline Isolate & Incidence & \% \\
\hline Staphylococcus aureus & 15 & 34.8 \\
\hline Staphylococcus sp & 6 & 14.0 \\
\hline Staphylococcus sp & 6 & 25.6 \\
\hline Bacillus $s p$ & 10 & 25.6 \\
\hline
\end{tabular}

Table 4: Incidence of Gram Negative Bacterial Isolated from Hospital Inanimate Object

\begin{tabular}{|l|l|l|}
\hline Isolate & Incidence & $\%$ \\
\hline Pseudomonas $s p$ & 9 & 33.3 \\
\hline Escherichia coli & 11 & 40.7 \\
\hline klebsiella $s p$ & 7 & 25.9 \\
\hline
\end{tabular}


Table 5: Antibiotic Resistance of Bacteria Isolate from Inanimate Object

\begin{tabular}{|l|l|l|}
\hline Isolates & Identification & Antibiotic To Which Isolate Was Resistance \\
\hline A & Pseudomonas $s p$ & AUG, CEX, COT, AMX, PFX \\
\hline B & Streptococcus $s p$ & NIT, COT, CPX, PFX \\
\hline C & Escherichia coli & AUG, TET, PEX \\
\hline D & Bacillus $s p$ & AUG, NIT, TET, PEX \\
\hline E & Klebsiella $s p$ & CEX, CPX, NIT, TET, PEX \\
\hline F & Staphylococcus aureus & AUG, TET \\
\hline G & Staphylococcus $s p$ & AUG, OLF, PFX \\
\hline
\end{tabular}

Keys: $\mathrm{AUG}=$ Augmentin, $\mathrm{GEN}=$ Gentamicin, $\mathrm{CHL}=$ Chloramphenicol, $\mathrm{AMX}=$ Amoxicillin, $\mathrm{TET}=$ Tetracycline, $\mathrm{COT}=\mathrm{Co}$-Trimoxazole, $\mathrm{PFX}=$ Pefloxacin, $\mathrm{OLF}=$ Olfloxacin, $\mathrm{NIT}=$ Nitromicin, $\mathrm{CPX}=$ Ciprophloxacin, $\mathrm{CEX}=$ Cephalexin, $\mathrm{PEX}=$ Trimethoprim (Trimpex)

\section{Discussion}

According to Madigan et al. [11], a hospital environment may not be a place where people get well but may also be a place where sick people get sicker. Infections in hospital environment are as result of the following factors: microorganism on hospital inanimate object, the compromised immune status of patients and the transmission chain of infections in hospitals.

The present study elucidate that certain pathogens were isolated from hospital inanimate objects. The result shows that the frequency of gram positive is higher than the gram negative. The observation of Cowan et al. [12] shows that staphylococcus was in consonance with the isolation of staphylococci and streptococci in the study however, the isolation of E. coli and Klebsiella $s p$. in this study is not apparently clear but could be associated with exposure to colonized patients. This present study reported that bacteria isolated from hospital object are mainly gram positive.

The alarming frequency with which microorganism on the hospital inanimate objects acquired resistance to antibiotics particularly by the mechanism of transmissible drug resistance and the fact that the antibiotics to which they remain sensitive are often highly toxic has nosocomail infection a serious problem [13].

\section{Conclusion}

This study shows that gram positive bacteria particularly Staphylococcus aureus, Staphylococcus sp., Bacillus sp. and Streptococci $s p$. were present on hospital objects and gram negative bacteria isolate ,the pathogens isolated particularly pseudomonas sp, E. coli and Klebisiella sp. can lead to serious health problem if not curb, education and awareness to paramedical staff, on simple hospital hygiene such as hand-washing using soap, periodic disinfection of hospital ward can reduce the incidence of pathogen in hospitals.

Antibiotics susceptibility tests indicate the presence of highly resistant bacteria in the hospitals sampled [14], and it may serve as a risk factor for the treatment of patients colonized with multiple-resistant strains of the bacteria with commonly used antibiotics.

\section{References}

[1]. Todar, K. (2003). Bacillus cereus and Food poisoning. Todar's online Textbook of Bacteriology.

[2]. Nakade Dhanraj, B., 2012. Antibiotic sensitivity of common Bacterial Pathogens against selected Quinolones. ISCA J. Biological Sci. 1(1): 77-79.

[3]. Adebayo-Tayo, A.C., N.N. Odu, M.U. Michael and I.O. Okonko, 2012. Multi-Drug Resistant (MDR) Organisms isolated from Seafoods in Uyo, South-Southern Nigeria. Nature and Science, 10(3): 61-70.

[4]. Colodner, R., Z. Samra, N. Keller, H. Sprecher and C. Block., 2007. First national surveillance of susceptibility of extended-spectrum $\beta$-lactamase-producing Escherichia coli and Klebsiella sp. to antimicrobials in Israel. Diagn. Microbiol. Infect Dis. 57(2): 201-205.

[5]. Depardieu, F., I. Podglajen, R. Leclercq, E. Collatz and P. Courvalin, 2007. Modes and modulations of antibiotic resistance gene expression. Clin. Microbiol. Rev. 20(1): 79-114.

[6]. Benoit D, Renaud L, Daniele M, Anne B, David B, Michael RM, et al. Variant Salmonella Genomic Island 1 Antibiotic Resistance Gene Cluster in Salmonella enterica Serovar Albany. Emerg. Infect. Dis 2003; 9(5):585-591

[7]. Cheesbrough, M., 2006. District Laboratory Practice in Tropical Countries. 1st Ed., Cambridge University Press, Cambridge, UK., ISBN-10: 0521665450, pp: 434.

[8]. Bauer, A.W., W.M. Kirby, J.C. Sherris and M. Turck, 1966. Antibiotic susceptibility testing by a standard single disc method. American Journal Clinical Pathology 451:493-496.

[9]. Halawani, E. and M. Shohayeb, 2008. Molecular Characterization of Multiple Antibiotic Resistance in Salmonella enterica Serovar Typhimurium and Eenteritidis Isolated in Saudi Arabia. World Journal of Medical Sciences 3 (2): 65-70.

[10]. Hsu, L.Y., T.Y. Tan, R. Jureen, T.H. Koh and P. Krishnan, 2007. Antimicrobial drug resistance in Singapore hospitals. Emerg. Infect. Dis., 13(12):1944-1947.

[11]. Madigan, M.T., J.M. Martinko, and J. Parker, 2000. Brock of Biology of Microbiology, $8^{\text {th }}$ Ed. Prentice-Hall, Upper Saddle River, Pp. 891-920

[12]. Cowan S.T., K.J. Steel, and J.P. Dgwd, 1960. A classification of the Klebsiella group. J. Gen. Microbiol. 23:601-612.

[13]. homas, K.R. (1987). Mutagenesis by gene targeting in mouse embryo-derived stem cell. Department of Biology, University of Utah Salt Lake City 6; 51(3): 503-12

[14]. Albrich, W.C., D.L. Monnet and S. Harbarth, 2004. Antibiotic selection pressure and resistance in Streptococcus pneumoniae and Streptococcus pyogenes. Group Journal of General Microbiology, 23:601-609. 